\title{
Audit Committee roles and responsibilities in two English public sector settings
}

\section{Purpose}

This paper conducts a comparative study by examining the Audit Committee (AC) set-up, roles, responsibilities and developments in two distinct UK public sector settings namely Foundation Trusts (FTs) and Local Authorities (LAs).

\section{Design/methodology/approach}

The paper is exploratory and explanatory in nature and uses a qualitative case study approach framed in institutional theory. It is based on semi-structured interviews with AC chairs, external and internal auditors, and finance directors triangulated with meeting observations and documentation review.

\section{Findings}

The study finds that public sector ACs have a large and diverse role which extends beyond challenging/monitoring responsibilities. Influenced by the New Public Management ideology the AC has developed more rapidly in FTs due to imposed regulation contrasting with the slower progress in LAs due to its still voluntary adoption. Nevertheless, in both environments there is a developing understanding and growing competence within the AC in terms of their assurance role where the focus has shifted from an emphasis on function and on transacting business through following a manual, to a more strategic-looking approach.

\section{Research implications/limitations}

Due to the complexity of public sector settings, and by using an approach framed within Institutional Theory, the study contributes by challenging a simple notion of isomorphism as an explanation of AC roles, responsibilities and development in two distinct public sector environments.

Furthermore, the study recognizes that there is a need to ensure ACs are appropriate to their institutional setting and organizational context.

\section{Originality/value}

Most AC studies have focused on private sector contexts. This paper explores the phenomenon in a different organizational context namely as a public sector comparative case study.

\section{Key words: Audit Committees, Public sector, Institutional Theory, Comparative case study, NHS Foundation Trust, Local government}

\footnotetext{
"This article is (c) Emerald Group Publishing and permission has been granted for this version to appear here (www.edgehill.ac.uk ). Emerald does not grant permission for this article to be further copied/distributed or hosted elsewhere without the express permission from Emerald Group Publishing Limited."
} 


\section{Introduction}

Audit Committees (ACs) in the UK public sector are not a new phenomenon, but over the years they have grown in significance as New Public Management (NPM) ideology has driven a shift from a traditional public administration to a management culture, based on the notions of privatisations, accountability for results, limited government interventions and economic liberalisation (Hood, 1991, 1995; Pollit and Bouckaert, 2011; Smyth, 2012). ACs were therefore introduced as formal mechanisms as part of the flurry of corporate governance codes for the public sector that largely mirrored the regulations of the 1992 Cadbury report (see for example NHS Trust Code of Governance, 1994 (since updated); Langland Report, 2004), although in most cases they adopted additional public sector values such as those of the Nolan commission (1995), with a focus on probity, accountability, openness and Leadership. Moreover, the concept behind them had been present in public sector for much longer in the form of Value For Money (VFM) audit. The latter, seen as a blend of a conventional audit approach and management consulting, was first introduced by the National Audit Act (1983) and aimed to secure the integrity of accounts as it enabled robust interrogation of the managers responsible for ensuring that underlying reported expenditure represented efficiency and was accurate (Glynn, 1985; Parker and Guthrie, 1993).

As part of an organisation's governance system the AC acts as an important monitoring mechanism with functions that include reviewing internal control systems, internal and external audit, compliance and governance arrangements. Typically, ACs have grown in significance following scandals which have led to requirements for greater assurance in organisations (Rogers, 2006). Private sector scandals have included Enron (2001), WorldCom and Quest. More recently scandals in the UK public sector such as the Mid Staffs hospital scandal (2009) [1] and the Winterbourne Grove (2011) failing [2] have led to a widening of the role of the AC in the public sector to encompass governance measures associated with ensuring good quality delivery of public services in addition to the established VFM requirement.

This paper is motivated by the paucity of empirical studies of public sector governance structures and mechanisms in comparison to the extensive private sector Corporate Governance (CG) research (Broadbent and Guthrie, 2008; Christopher, 2010). Public sector CG issues go further than private sector issues as stewardship of public funds is prioritised, meaning that transparency and due process requirements exceed the corporate sector requirements. "This article is (c) Emerald Group Publishing and permission has been granted for this version to appear here (www.edgehill.ac.uk ). Emerald does not grant permission for this article to be further copied/distributed or hosted elsewhere without the express permission from Emerald Group Publishing Limited." 
Furthermore, projects are often deemed more complex given the interest of the multiple stakeholders with various legitimate but often conflicting accountability expectations (Evan and Freeman, 1990). The complex processes, structures and requirements in a public sector context and the lack of studies in this area, as highlighted by Pollitt (2011), constrains our understanding of how CG mechanisms contribute to the performance of public sector organizations and consequently this research aims to address this gap.

Moreover, the few studies that do exist about ACs in a public sector context show that, whilst public sector ACs are distinctive in that they exist in various forms and structures (Boardsource, 2010), there is insufficient knowledge about the AC set-up and its wider responsibilities. In addition, there is no comparative study on ACs in a UK public sector context as the few studies that do exist examine ACs in a single organisational context or institutional setting (Van der Nest, 2008; Magrane and Malthus, 2010; Davies, 2009; Chien et al., 2010).

The main purpose of this paper is to examine and compare the Audit Committee (AC) set-up, roles, responsibilities and development in two distinct UK public sector contexts, namely Foundation Trusts (FTs) and Local Authorities (LAs). It examines whether Institutional Theory (IT) and the related concept of isomorphism can offer sufficient explanation of how these ACs have come to be imported into public sector organisations via the implementation of Codes of Corporate Governance derived from the Cadbury Code and successive UK Codes of Corporate Governance. The paper recognizes that a "one size fits all” approach, in terms of the AC setup and its operations, is not uniform across the public sector as a whole and thus, enables a better understanding of the structures and processes of the AC and the way in which they are developing. It extends previous work on ACs in two distinct ways by addressing the following overarching research question:

How do the AC set-up, roles, responsibilities and development differ between FTs and LAs?

First, this paper responds to calls for more research on the operations, roles and responsibilities of ACs in a variety of organizational contexts (Spira, 2003; Beasley et al., 2009; Pridgen and Wang, 2012). It also provides details on the operational conditions of AC activities relating to perspectives in two distinct institutional settings (Turley and Zaman, 2007).

Second, despite the diversity of the AC roles most research on ACs in the private sector and "This article is (c) Emerald Group Publishing and permission has been granted for this version to appear here (www.edgehill.ac.uk ). Emerald does not grant permission for this article to be further copied/distributed or hosted elsewhere without the express permission from Emerald Group Publishing Limited." 
the limited literature on ACs in a public sector context has focused on the structural characteristics of ACs, including the AC's independence, financial expertise, meeting frequency or on whether ACs comply with related rules, regulations or codes of governance (Bedard et al., 2008; Xie et al., 2003; Liao and Wen-Hsin Hsu, 2013; Higgs, 2003; Spira and Bender, 2004; Carcello and Neal, 2003;; Larcker et al., 2007). In addition, most of the AC studies are relational and research objective studies which explore relationships between measurable characteristics of the AC and indicators of effectiveness (Bedard and Gendron, 2010).

There remains however a rarity of exploratory and explanatory studies on the operation of ACs and understanding why and how the association between AC characteristics and other variables happen (Turley and Zaman, 2004). This paper uses a qualitative case study coupled with document reviews and observation of AC meetings to examine how ACs differ between FTs and LAs in terms of their organisation, roles and responsibilities, and development.

The paper proceeds as follows. The next section presents the background on FTs and LAs and is followed by a review of relevant literature which examines ACs in different organizational contexts and institutional settings. The fourth section presents the theoretical framework and the research methodology used. The fifth section presents the research findings followed by a discussion section and lastly a short conclusion.

\section{Context and Background to English Public Sector Audit Committees}

A key influence on the implementation of public sector ACs has been the neoliberalist reform of the public sector in general based on the notions of privatisation, limited government intervention and economic liberalisation (Pollit and Bouckaert, 2011; Smyth, 2012). New Public Management (NPM), a term formally conceptualized by Hood (1991), denotes the government policies that since the 1980s have aimed to modernise the public sector. There was a need to "reinvent government", transform the public sector and banish the bureaucracy. Hood (1991, 1995) identifies some key elements of NPM which include: the use of private sector management styles, a hands-on top management [3], formal measurable standards and measurement of performance. NPM was mainly geared towards pushing the state to managerialism away from more traditional public administration (Ghobadian et al., 2009). This also included a move towards economizing the notion of accountability (Humphrey and Miller, "This article is (c) Emerald Group Publishing and permission has been granted for this version to appear here (www.edgehill.ac.uk ). Emerald does not grant permission for this article to be further copied/distributed or hosted elsewhere without the express permission from Emerald Group Publishing Limited." 
2012), that is notions of efficiency, financial management and VFM gained much more ascendancy and importance (Aristovnik, 2009).

As a mechanism stemming out of corporate governance reforms in the public sector, the AC is therefore part of the NPM reform process. NPM mechanisms are not invariant or absolute but constantly developing at different speeds in different settings and are inherently liberating or constraining (Pollitt, 2011), therefore a "one size fits all” approach is unlikely to be appropriate for ACs in different public sector settings as environmental pressures and institutional settings vary.

Due to the limitation of previous studies on ACs operations in different institutional settings and organizational contexts (Turley and Zaman, 2007), this study made the choice to examine the ACs operations, roles and responsibilities and provide evidence on their development in FTs and LAs, two distinct public sector settings. Following pilot interviews, it became clear that health and local government have distinct histories, characteristics and processes, and as they are the two largest public sector areas they offer suitable fields for comparison.

Within health, the NHS Foundation Trusts (FTs) are a new organisational form and represent a good example of the application of NPM techniques to the public sector. FTs were created and set up as separate and independent legal entities. Through their centralized top down management structure their governance model and structure is the closest in similarity to a private sector CG model. They have a board of governors who are elected by members of the FT, a subsection of whom serve on the AC.

In contrast Local Authorities (LAs) have a long established history dating back in some instances to the Anglo Saxon times. They therefore bring a wealth of tradition and piecemeal organizational structural change which makes it hard to impose governance new structures and regulations. LAs are created by Acts of Parliament and are set up as statutory autonomous bodies which can raise taxes locally. They are political in nature and are directly accountable to their electorate. Some elected local councillors occupy the executive roles in the LA whilst others fulfil roles on the various committees, of which the AC is one.

FTs and LAs, which differ in terms of their histories, structures and processes, therefore provide a good contrast to tease out differences in how and why their AC set-up, roles and

\footnotetext{
"This article is (c) Emerald Group Publishing and permission has been granted for this version to appear here (www.edgehill.ac.uk ). Emerald does not grant permission for this article to be further copied/distributed or hosted elsewhere without the express permission from Emerald Group Publishing Limited."
} 
responsibilities have developed. A more detailed description of each organizational form follows.

\section{A) Foundation Trusts}

FTs, first introduced in April 2004, are a new organisational form under the NHS. Parliament created FTs as independent legal entities through the 2003 Health and Social Care Act and provided them with independence from central government. The aim was to have a patient- led NHS and devolve decision making from a centralized NHS to local communities so as to be more responsive to patient needs. As self-standing, self-governing organisations, FTs are free to determine with their governors and members, their own strategy and make their own decisions on the way services are run. FTs are accountable to their local communities through their members and governors, to Parliament by laying out their annual reports and accounts before them, to the Care Quality Commission to register and meet the associated standards for the quality of care provided and finally to Monitor as their regulator. FTs have a governance structure that ensures participation in the strategic planning of the organisation from within the local communities that they serve. Governors are direct representatives who have an interest in helping their community and whose role is to challenge the board of directors and hold them to account for the trust's performance. Governors are held accountable to Monitor, which is the sector regulator for health services in England and responsible for authorising, monitoring and regulating FTs. Monitor's role includes ensuring that FTs comply with the conditions they signed up to, the required quality standards, that they are well-led and financially robust. Additionally, the Code of Governance for FTs set by Monitor sets out a common overarching framework for the CG of FTs. The aim of the code was to bring best practice from the private to the FT sector with the ultimate goal of ensuring a strong governance structure is in place to enable high-quality patient care. FTs are required to comply with the main principles of the code in relation to the AC set-up and responsibilities and if not provide justifications for their non-compliance. This includes having a mix of Non-Executive and Executive directors whose

role includes scrutinizing the integrity of the accounts, financial controls and clinical quality arrangements.

\section{B) Local Authorities}

LAs are mid-tier bodies within English public administration. They are statutory autonomous bodies, created by Acts of Parliament (Local Government Act 1992), independently elected, able to raise taxes locally and are directly accountable to their electorates. Local councils are "This article is (c) Emerald Group Publishing and permission has been granted for this version to appear here (www.edgehill.ac.uk ). Emerald does not grant permission for this article to be further copied/distributed or hosted elsewhere without the express permission from Emerald Group Publishing Limited." 
funded by a combination of central government grants, council tax, business rates, and fees and charges. Central government and the legal system provide some oversight to LAs, but each authority is ultimately responsible to the local people who elect the councillors. Councillors are typically elected either as members of political parties or as independents. Thus, LAs are political subdivisions of a state and generally act within the powers delegated to them by the Department of Communities and Local Government.

The Framework 'Delivering Good Governance in Local Government'” (CIPFA, 2007 (last updated in 2013)) defines the principles underpinning the governance of each local government body and provides guidelines for a good governance structure including promoting values for the organisation, taking informed and transparent decisions, and managing risk. However, in contrast to FTs, LAs have considerably more choice in determining how to set up the AC and other governance committees.

\section{Literature review}

ACs have remained understudied in public sector organisations due to their relative newness compared to the private sector, and to the extra difficulties of studying such structures in diverse and complex environments. Prior public sector research has largely followed the pattern set out by researchers examining the composition, role and effectiveness of private sector ACs (Spira, 2002; Turley and Zaman, 2004 \& 2007, Ghafran and O'Sullivan, 2013; Liao and Wen-Hsin Hsu, 2013).

Cadbury (1992) first recognized that appropriately structured ACs have the potential to improve the quality of financial reporting and the independence of audit. Research on ACs in the corporate sector can be segregated into two stages or time periods. Earlier work surrounding ACs focused on issues surrounding the formation of ACs and how they influenced specific aspects of corporate behaviour. The aftermath of the Enron scandal in 2001 changed the nature of academic research on ACs. As a result of private sector scandals the more prescriptive regulations of ACs over the past decade has moved the nature of research on to AC characteristics and operations and what impact they might have on specific aspects on the financial reporting process (Ghafran and O’Sullivan, 2013).

Most private sector researchers have inevitably relied on relatively crude proxies, for example, the number, frequency and duration of AC meetings, the percentage of AC members and

"This article is (c) Emerald Group Publishing and permission has been granted for this version to appear here (www.edgehill.ac.uk ). Emerald does not grant permission for this article to be further copied/distributed or hosted elsewhere without the express permission from Emerald Group Publishing Limited." 
independent Non-Executive Directors (NED) possessing financial expertise as indicators of how "effective" an AC is (Bedard et al., 2008; Xie et al., 2003; Spira and Bender, 2004; Larcker et al., 2007). Furthermore, a further sphere of studies were constructed to test whether there is an association between AC characteristics and other variables of interest (Abbot et al., 2004; Carcello and Neal, 2003). These include instances of alleged fraud and misstatements or restatements (Archambeault et al., 2008) and the role of AC in the provision of non-audit services (Zaman et al., 2011;).

However, given the complexity of the public sector environment and the difficulties of data collection in comparison to the corporate sector where relevant information can be collected via databases, most existing public sector research takes the form of case studies.

Prior studies have examined the independence and financial expertise aspects of AC members (Vermeer et al., 2006; West and Berman, 2003). They have found that ACs function rather weakly in the non-profit sector (Miller, 2002; Hillman and Dalziel, 2003) and that public sector and non-profit ACs are distinctive, they exist in various forms and structures and have much more diverse structures and working mechanisms when compared to corporate ACs (BoardSource, 2010). As ACs are still relatively new in many public sector organisations there is evidence that implies the AC members still lack a proper understanding and experience of their duties and have to become more familiar and gain more expertise with operational processes and matters relating to the public sector overall. One of the few exploratory studies and which examined the functioning of the AC in a South African public sector context, using semi-structured interviews imply that AC members have to become more familiar and gain more expertise with operational processes and specifically matters relating to the public sector overall (Van der Nest, 2008). A further study, focusing on a case study of a single district health board in the public sector in New Zealand find discrepancies and which show that although ACs have been adopted AC members still lack proper understanding and experience of their duties (Magrane and Malthus, 2010).

A further important issue is how ACs function and whether they possess the skills needed to fulfil their role of monitoring in a substantive and effective way. Purcell et al., (2014) examined the AC effectiveness in Victorian Local Government and also found limitations to effectiveness in relation to the variability of expertise and skills of the AC members and the need for a continuing development for members. The majority of studies though, similar to the studies in "This article is (c) Emerald Group Publishing and permission has been granted for this version to appear here (www.edgehill.ac.uk ). Emerald does not grant permission for this article to be further copied/distributed or hosted elsewhere without the express permission from Emerald Group Publishing Limited." 
a private sector context, have rather inevitably relied on relatively crude proxies to examine specific AC components, or finding correlations between AC elements and other company characteristics (Rainsbury et al., 2012; Pridgen and Wang, 2012; Chandrasegaram et al., 2013; Rich and Zhang, 2014).

Thus, studying the association between AC components indicates some aspects of the conditions for certain governance outcomes, but does not reveal the processes and manner of how ACs perform in practice involving their set-up, roles and responsibilities. The contribution

of using a qualitative case study approach as in this paper, assists in "investigating AC processes within their organizational context to reveal more of what is unobservable in externally available data” (Turley and Zaman, 2007, p.4).

The scant existing literature on the ion of ACs in a public sector context means that there is a need for further exploratory research. This helps gain a better understanding of how ACs are composed and how they operate in practice in different public sector settings and organizational contexts. This paper particularly examines the AC set-up and responsibilities in FTs and LAs whilst providing evidence on their development.

\section{Theoretical framework and Research method}

\subsection{Theoretical framework}

For its theoretical framework this research uses Institutional Theory (IT), as this is the most common theoretical approach used in public sector accounting research (Jacobs, 2012), and has increasingly been applied to study the practice of accounting in organizations (Dillard et al., 2004). Its central proposition is that institutional environments impose structural uniformity on all organizations in modern societies (Meyer and Rowan, 1977; DiMaggio and Powell, 1983). IT generally considers changes in organizational processes over time (Cohen et al., 2002, 2007) and provides explanations as to why organizations take similar characteristics and forms over time. Since the implementation of NPM reforms into the public sector, some researchers claim that the public sector has moved to a more corporate, competitive and professional mode of operation (Dart, 2004; Myers and Sacks, 2003) and this transition has necessitated the adoption and embedding of institutionally acceptable practices at organizational level.

\footnotetext{
"This article is (c) Emerald Group Publishing and permission has been granted for this version to appear here (www.edgehill.ac.uk ). Emerald does not grant permission for this article to be further copied/distributed or hosted elsewhere without the express permission from Emerald Group Publishing Limited."
} 
In addition, IT has a political core that points to public sector organizations being the drivers and triggers of institutionalization due to isomorphic mechanisms whereby organizations become increasingly homogenous within given domains and conform to expectations of the wider institutional environment. Such a move views organizations as operating within a social framework of norms and values and tending to conform so as to be rewarded with increased legitimacy, resources and survival capabilities (Hawley, 1968). Given the centrality of regulation in this study in the form of CG codes and guidelines which govern the AC set-up and responsibilities, isomorphism is an important element which needs to be considered in analysing public sector ACs.

Within isomorphism different processes of adaption and change can be identified (DiMaggio and Powell, 1983). Mimetic isomorphism is a process that takes place when organizations attempt to imitate or model themselves after a more successful and legitimate referent organization, often due to the uncertainty and lack of guidance in their own environment. Mimetic isomorphism can be contrasted with coercive isomorphism, which takes place when external stakeholders or other entities put pressure on an organisation to change. Institutional pressures in highly institutionalised environments are expected to produce organizational responses, although not necessarily uniform ones across different organisations. This study aims to examine whether, and if so how, isomorphic tendencies have influenced the role and development of ACs in two different public sector organizational contexts and institutional settings which differ in terms of their histories and structures.

\subsection{Research method}

This research draws on a qualitative case study methodological approach which includes semistructured interviews, document reviews and observation of meetings. The benefit of using multiple research methods as in this study provides in-depth insights into examining ACs in an organizational context and provides increased verification and validity.

A case study approach was chosen for this study as it assists in understanding the governance structures and AC set-up and operations in the UK public sector by getting deep insights from within organisations which are beneficial when engaging with practice (Yin, 2003). We used a two-step process for selecting two FTs and two LAs to study in depth. First we assessed the level and degree of compliance with the requirements for ACs embedded in their respective governance codes. For the FT sector all 144 FTs in existence at the year-end 2011/2012 were

"This article is (c) Emerald Group Publishing and permission has been granted for this version to appear here (www.edgehill.ac.uk ). Emerald does not grant permission for this article to be further copied/distributed or hosted elsewhere without the express permission from Emerald Group Publishing Limited." 
tested for compliance with AC elements through a manually designed checklist from Monitors' Code of Corporate Governance, (2010 (last updated in 2014)) including elements about the composition, role and operations of ACs. As there is no CG code for local government but rather a CG framework (Audit Committees-Practical Guidance for Local Authorities, 2005 (last updated in 2013)), which sets out guidelines on best practice for ACs, it was used as a guidance to check on what is publicly available on the LAs websites regarding ACs.

Based on the results of the compliance testing four FTs and four LAs reflecting both high and low levels of compliance were chosen for further investigation. This later reduced to two FTs and two LAs based on the organizations' willingness to be interviewed, the research objectives, type of the FT, political structure of the LA and the accessibility of the organizations chosen. For anonymization purposes the FTs chosen for case study were named North and South whilst the LAs were named East and West.

In order to gain access to the AC Chairs in FTs the snowball sampling method was used. Finance Directors (FD) were chosen as a first means of contact, and through them interviews with the AC Chair were arranged. Then, due to the privacy requirements in FTs, the AC Chairs were asked for permission to attend AC meetings on an observation-only basis. Whilst this was granted, no papers or minutes are publicly available and the researcher had to make notes.

In contrast, the political structure of LAs means that AC Chairs, as they are elected councillors, are very accustomed to interacting with a wide range of public enquirers and were helpful in replying and agreeing to be interviewed. AC committee meetings are open to the public except for any restricted business of a confidential nature. Minutes and some papers are made publicly available on LA websites. Attendance at meetings in both FTs and LAs gave the opportunity to arrange further informal or formal meetings with the internal and external auditors. In total 22 interviews were carried out in the four organisations (see Table 1).

(Insert table 1 here)

Semi-structured interviews were predominantly used to gain insights from within organisations on how the ACs operated in practice. They helped to uncover any non-visible data which may be due to limitations of secondary resources and to seek confirmation and clarity to increase data reliability (Rea and Parker, 2012). Before the interviews took place publicly available data was examined to generate a set of questions, including points about the role of the interviewee,

"This article is (c) Emerald Group Publishing and permission has been granted for this version to appear here (www.edgehill.ac.uk ). Emerald does not grant permission for this article to be further copied/distributed or hosted elsewhere without the express permission from Emerald Group Publishing Limited." 
follow-up and confirmation of information coming out of the compliance testing results, and details about the appointment of members, make-up, role and responsibilities of the AC.

As found by Mckernan and Mckernan (2013), meeting observations provided supplementary insights and verifications of participants' claims as well as confirmation of documentary reviews. This helped gain more insight into how AC meetings are conducted in practice and how officers are held to account for their actions and challenged.

All interviewees were chosen due to their knowledge of the working of the AC and their understanding of both financial and other relevant information that falls under the scrutiny of the AC. It was possible to digitally record many of the semi-structured interviews, following which they were transcribed. Informal discussions held with the Internal Auditor and External Auditor after the AC meetings were more unpredictable and not digitally recorded; instead notes were made.

Additional supplementary data was gathered from relevant public sector and government websites such as Monitor, annual reports, public service rules and guidelines, codes and frameworks, news and press items and board minutes and agendas. Examining such documents was used as part of a triangulation process to compare and interpret information, and reveal any contrasting views between interviewees' responses and the written records. The data collected was then analysed, using the conventional approach where coding categories and themes are derived directly from the text.

Having explained the research approach, the next section presents the evidence gathered in response to the research objective of providing a detailed examination of the operation of ACs in two distinct public sector contexts.

\section{Research findings}

The evidence found demonstrates that ACs, in terms of their set-up, roles and responsibilities, have developed in different ways due to the different public sector contexts in which they operate. Findings are presented under three major emergent themes. First the material regarding the AC composition is contrasted between FTs and LAs. Second the role and responsibilities are compared. Finally, ongoing improvements and developments are discussed.

\footnotetext{
"This article is (c) Emerald Group Publishing and permission has been granted for this version to appear here (www.edgehill.ac.uk ). Emerald does not grant permission for this article to be further copied/distributed or hosted elsewhere without the express permission from Emerald Group Publishing Limited."
} 


\subsection{The AC composition, including size, appointment and membership}

The Monitor Code of Governance (2014) and the CIPFA Guidelines on AC membership (2013) set out what is expected in terms of the main requirements and characteristics in regards to the ACs' composition in FTs and LAs. Table 2 provides a comparison of Monitor and CIPFA rules and guidelines, and how the FTs and LAs in our study comply with them. Whilst the Monitor Code of Governance (2014) and the CIPFA Guidelines on AC membership (2013) are quite similar in terms of suggested numbers for membership, only Monitor requires members to be independent non-executive directors (NEDs), thus demonstrating its close derivation from the UK Code of Corporate Governance (2014). Both FT cases comply with Monitor's requirements of at least three independent NEDs, with North having 6 and South 5 members. This is in contrast to both LAs, where numbers are over double the CIPFA Guidelines. East has 11 members whilst West has 10 members. There are two reasons for this excess. First, each AC contains two independent members in addition to councillors, who have been brought in to add both relevant experience and greater representation of the public interest. Second, LAs' political nature requires a greater number of members on the AC to ensure balance among the range of committees across the political structure of local government.

Insert Table 2 about here

Monitor's code makes no mention of the appointment process, yet this is important given the need to ensure there is appropriate balance of relevant qualifications, skills and experience held by AC members.

"The board should satisfy itself that the membership of the audit committee has sufficient skills and experience to discharge its responsibilities effectively” (Monitor, 2012) page 38).

For LAs, the CIPFA code recognises that there will be differences, as it notes that membership must abide by the rules concerning the LA's political structure, and historically these vary between LAs. The political nature of LAs also makes it presence felt in terms of the length of appointment. Whilst for FTs AC members are initially appointed for three years (with possible extension), for LAs there is an annual appointment process following local government elections in May. Whilst this has the potential to lead to significant change in AC membership each year, in both East and West most councillors tended to remain on the same committee to

"This article is (c) Emerald Group Publishing and permission has been granted for this version to appear here (www.edgehill.ac.uk ). Emerald does not grant permission for this article to be further copied/distributed or hosted elsewhere without the express permission from Emerald Group Publishing Limited." 
ensure experience built up over time.

In both East and West LAs, councillors who do not hold executive positions have some degree of freedom in choosing which committees they wish to serve on, subject to positions being available plus it being usual for the AC to have representation from both the ruling party and the opposition. However, this element of choice may be a drawback - the East AC Chair confirms that: "no problem on the AC because we are glad for anyone to join". This quote indicates implicitly that being a member of a regulatory scrutiny-type committee such as the AC remains less popular with councillors than being a strategy-related committee, as there they can gain a higher profile and thus potentially a higher public profile and more support from the electorate. It is difficult to establish whether this has any effect on the quality of AC members compared to other committee members. The political nature of LAs also constrains choice of AC Chair, although here the rules vary. In West, following established democratic rules, the requirement is that the Chair is a member of the opposition party and the small number of elected opposition councillors means there is very limited choice. East does not follow this rule and the Chair is a member of the ruling party.

In terms of criteria on experience, Monitor's code is far more prescriptive than the CIPFA guidelines, and there is consequently considerable diversity of AC membership in the four organisations studied. Regarding financial experience, Monitor requires one member, preferably the AC Chair, to have recent and relevant financial experience. Both North and South FTs meet this requirement. Since LA ACs are made up of elected members who come from a huge variety of backgrounds, CIPFA guidelines do not have a requirement for financial experience and we found that many councillors only have a general business understanding. Instead the guidelines encourage the injection of an external view through the co-option of local independent members. Both East and West benefit from having independent members who are accountants and therefore bring financial expertise to discussions. They help to ensure proper scrutiny of work and make sure VFM is achieved. Independent members are treated the same as AC councillor members and have full voting rights and authority in the AC meetings.

As well as financial experience, it is seen as crucial in both the Monitor code and CIPFA guidelines that the AC covers a broad spectrum of expertise and skills.

"In order to be effective an Audit Committee needs a chair and membership that has

"This article is (c) Emerald Group Publishing and permission has been granted for this version to appear here (www.edgehill.ac.uk ). Emerald does not grant permission for this article to be further copied/distributed or hosted elsewhere without the express permission from Emerald Group Publishing Limited." 
knowledge, experience and interest in the field. The committee will benefit from members with financial awareness, independence of thinking and balanced approach to significant issues." (CIPFA, 2007 p.19)

The North AC Chair agrees with this: “It is crucial as the best questions don't always come from the people with the most obvious qualification for that." In South, besides the Chair having financial experience, the other members should have an enquiring mind and a general business understanding (ideally one member with some health background) thus have the relevant skills to cover their diverse duties effectively. Moreover, all AC members have the powers entitled to NEDs with regard to the influence they can exert as they are able to challenge and make recommendations to the board. The two FT ACs therefore have good collective experience and multiplicity of skills. They are competent to cover the wide range of healthcare requirements taking account of the different stakeholder groups and their needs. 'I think it's helpful and would do no harm having someone else with financial experience but we only have a limited number of NED and need to ensure we have people with a business acumen, legal and health background. This enables people to ask different questions which are very useful (Finance Director North).

The very different nature of member appointment for LA ACs means that relevant experience and skills cannot be specified in advance, something that the East AC Chair considers a strength: "We never have any trouble appointing as you don't have to have any skills base to do that and I think that is a good thing.” The larger number of members on the LA AC combined with the ability to co-opt independent members with specific experience does mean that overall there is a wide range of skills and experience, necessary to cover the large number of LA functions.

In relation to training, for both North and South all new AC members are subject to induction training on appointment, with a focus not only on financial aspects but also on specific NHS elements such as clinical matters. Due to the more extensive membership turnover and larger size of the LA ACs, regular training sessions are available in addition to induction training which covers the role of the AC, its terms and references and main activities.

In summary, the FT ACs are small and stable, and are comprised of members with extensive and complementary experience. In contrast, LA ACs have the potential for extensive annual

"This article is (c) Emerald Group Publishing and permission has been granted for this version to appear here (www.edgehill.ac.uk ). Emerald does not grant permission for this article to be further copied/distributed or hosted elsewhere without the express permission from Emerald Group Publishing Limited." 
membership change. Although membership consists of democratically elected councillors who may or may not have relevant experience, this problem can be managed as the size of the AC is larger than in FTs, thus offering a larger pool of expertise and knowledge, and any gaps in expertise are overcome through the co-opting of independent members with the necessary skills.

\subsection{The AC role, responsibilities and operation}

As a significant CG mechanism, the main role of the AC in both FTs and LAs is to monitor executive performance. Due to the different organisational structures and remits of FTs and LAs there are differences in how this role is delivered, however both types of public sector entity AC share the common themes of monitoring systems and processes in terms of both financial and non-financial performance, including liaison with both internal and external audit functions, and holding management to account. One interviewee summed it up as: 'Ultimately the AC role is an assessment of how effective we are being and if people are doing what they are asked to do" (Internal Auditor East). Monitoring of risk management is another important component, although for some of the cases in this study it overlapped with the remit of an additional scrutiny committee. Such overlap was seen as good as it adds rigour to the scrutiny system.

Monitor's term of reference for FTs requires ACs to monitor the integrity of the financial statements, review the internal financial control and risk management systems, monitor and review the effectiveness of the internal audit function and the review the external auditor's independence and objectivity (Monitor, 2014). A high proportion of the AC's work relates to financial matters, especially the review of significant financial reporting judgements made by the executive and the scrutiny and approval of the annual accounts. A key target for the AC to monitor is the financial risk rating which reflects the risk to the FT's continuity. Whilst the CIPFA Guidelines are less prescriptive, there is still an emphasis on considering the effectiveness of governance mechanisms such as risk management arrangements and the control environment. The LA AC is also responsible for reviewing the annual statement of accounts.

Both FT and LA ACs have responsibility for ensuring that internal systems and controls operate effectively, and this responsibility extends beyond the monitoring of financial activities. One interviewee particularly emphasised the importance of having a wide outlook on issues that the

\footnotetext{
"This article is (c) Emerald Group Publishing and permission has been granted for this version to appear here (www.edgehill.ac.uk ). Emerald does not grant permission for this article to be further copied/distributed or hosted elsewhere without the express permission from Emerald Group Publishing Limited."
} 
AC should consider: "I would tend to encourage the AC to review certain areas and the AC have to have some element of free reign to look at whatever they want for whatever reason they want. It means they own the $A C^{\prime \prime}$. The $\mathrm{AC}$ also has responsibility for reviewing the effectiveness of the Internal Audit Function and for monitoring the relationship with the External Auditor so that there is assurance that management action has been taken where necessary. This responsibility is more visible in LAs than FTs, where in addition there is more emphasis on anti-fraud and anti-corruption arrangements.

Quality around service delivery has especial importance, although in practice there is a difference in emphasis. In FTs clinical governance has become very prominent, with the AC seen as being a key part of the organisations' mission to deliver key objectives of high quality care and clinical governance elements, as this quote demonstrates: "The AC can be seen as boring but it's quite powerful that it sends a message that says let's not pretend all of this is glamorous and exciting and like something out of a James Bond film. What people see is that the AC cares passionately that the organisation is being able to deliver high quality care. It's sending a message and also helps them to understand. It's also that kind of clinical stuff where we seem to spend quite a bit of our time." (AC Chair South). The increased reviewing of clinical aspects in both FTs such as focusing around meeting national targets such as the quick access of patients to treatments or the percentage of cancelled operations, has gained in importance because of the previous governance failings in the NHS sector. In contrast the following quote from AC Chair North emphasises that ensuring financial efficiency remains the top priority in terms of AC workload: "However we only expand into clinical aspects once there is basic assurance that the financial systems are sound, proper and scrutinize well." For LAs, the diverse range of services delivered means that the focus is on achieving VFM across the board.

All parties saw an important responsibility of the AC as being the ability to challenge the executives and other officers and therefore to hold people to account, thus providing assurances on the adequacy of controls and procedures. For example, in North the NEDs asked the clinical director for neurology to attend the AC meeting and explain how consent is gained from a patient in neurology before they can be treated. For the Finance Director of South, the opportunity for face-to-face communication strengthens the AC role in the overall organisational structure: "I think the AC get more confident when people come and talk to them

"This article is (c) Emerald Group Publishing and permission has been granted for this version to appear here (www.edgehill.ac.uk ). Emerald does not grant permission for this article to be further copied/distributed or hosted elsewhere without the express permission from Emerald Group Publishing Limited." 
directly and thus get a sense of some of the stuff we talked about at the board. I feel like it's reasonably embedded in the way people work.' Similarly, the LA AC also has the power and right to call any officers, officials or agencies into the AC meeting and challenge them as required or demand more explanations. Here the LA AC's objective should be to ensure that arrangements are in place for the proportionate and independent investigation and for appropriate follow-up action, for example, dealing with whistle-blowers: "So it does deal with any whistleblowing to say that $x$ member of Staff has been seen doing a certain thing in terms of council led services or funding. This investigation forms part of our role as an AC' (External Auditor East).

In summary, in both FTs and LAs the majority of the AC work deals with financial aspects. Nevertheless, there has been increased emphasis on specific public sector characteristics such as clinical governance elements in FTs and VFM in LAs. Furthermore, AC members in both environments have the power to hold officers to account for their actions and challenge them as required in the AC meetings.

\subsection{How the role and work of the AC have developed}

The research findings provide evidence that there have been improvements and a better understanding over time of the AC roles and responsibilities in FTs and LAs. The most notable improvement has been the shift over time from the AC being a functional committee which transacted its business in accordance with the manual of the time and where the agenda was largely created by the Chief of Internal Audit. One interviewee recounted how the AC would look at all sorts of really ' 'dull' things that were not material in the running of the business. 'So during the time after becoming a FT we started to shape the committee by giving NEDs the freedom to look at whatever they want and to move the work of the AC focus away from a routine." (FD South). Another noted that: "we could have played a tape instead of having an AC as they used to go through the motions before" (AC Chair South).

For FTs significant development “absolutely unequivocally and definitely” (AC Chair South) took place as the Mid-Staffordshire hospital scandal and consequent Francis Report (2010) meant that ACs were castigated for only focusing on financial governance to the detriment of clinical governance issues. Monitor moved to set a higher level of expectations from NEDs and by large NEDs have responded to that well.”. There should be nothing to surprise them and "This article is (c) Emerald Group Publishing and permission has been granted for this version to appear here (www.edgehill.ac.uk ). Emerald does not grant permission for this article to be further copied/distributed or hosted elsewhere without the express permission from Emerald Group Publishing Limited." 
they are in a perfect situation to react or go and seek help from Monitor” (AC Chair North). Additionally, besides the increased focus on monitoring and scrutinizing responsibilities, the AC is encouraged to take up particular roles in putting patients first, having strong leadership and supervision duties and undertaking independent scrutiny of the internal control assurances from management." I hope people say the AC is not just a dead hand but can be a force for good and for change', (FD South). This enhanced role of assurance for the AC, where the focus has shifted from small details to strategic related targets, aims and goals.

Whilst for FTs it was the NEDs, with their extensive relevant experience, driving reform, within the LAs examined in this study it was the External Auditor (EA), in conjunction with Internal Audit (IA), who took this role. When ACs were relatively new councillors tended to have gaps in their knowledge and experience and so did not feel comfortable with regards to their new role. AC meetings therefore struggled to rise above the political dimension. In East, therefore, the EAs reviewed the AC arrangements to take it away from a political to a more strategic level. This process has been ongoing in liaison with the Internal Audit: "It has been progressing since we have been here and we meet regularly with the IA as we are the main two parties that report in every meeting" (External Auditor East). Over time councillors' experience and understanding have improved and with that the governance process also: " $I$ think now everyone knows it's there and how it fits and what assurances it is providing. The $A C$ is key in making sure people are accountable and fulfilling their role effectively and one of those preventative things are control and respect” (AC Chair East).

The AC Chair in West further confirms that the reports that are being taken to the AC nowadays are quite insightful and the majority of them are becoming clearer and purposeful than before. "If you look back at 2006 there tended to be like 2 agenda items and now we get a good 10 items. There is respect in the room by the executives because they know they can be challenged'. Moreover, there is a good level of debate in the AC meetings on different topics "and once you get pulled into an AC you are going to start implementing that action. Thus it's an element that is constantly improving" (Internal Auditor East).

Furthermore, AC members in LAs recognize that holding members to account is a very important aspect of their role. "Having an AC has made departments, managers, political heads, and directorates more accountable. So that's actually improved accountability, and has got us moving in the right direction. I would say it's been a positive improvement "(Internal "This article is (c) Emerald Group Publishing and permission has been granted for this version to appear here (www.edgehill.ac.uk ). Emerald does not grant permission for this article to be further copied/distributed or hosted elsewhere without the express permission from Emerald Group Publishing Limited." 


\section{Auditor West).}

In summary, there is evidence that there have been improvements in the AC arrangements and in the understanding of the AC roles in FTs and LAs. Examples include the AC's extended role which includes holding people to account for their actions, focusing more on clinical aspects in FTs and having more freedom to decide on what issues to challenge in LAs. Also there have been developments within the remit of the AC evidenced by the move towards more strategic level discussions in the AC meetings in FTs and LAs. In addition, and due to the close contact to Monitor, NEDs in FTs are more aware of the high level of expectations from them in terms of their challenging responsibilities whereas in LAs councillors on the AC have a better perception of their assurance role and how the AC fits into the LA.

\section{Discussion}

This paper through a qualitative case study approach has examined the composition, roles and development of ACs in two distinct UK public sector environments. Though institutional pressures in highly complex environments are expected to produce organizational responses, these are not necessarily uniform across all functional sectors. Accordingly, responses to change vary between FTs and LAs especially in the development and operation of their ACs. The Institutional Theory lens used for this study shows that the regulation of ACs in the two environments demonstrates different isomorphic tendencies. There is clear mimetic isomorphism in FTs, where Monitor is a strong example of how NPM reforms have been applied in certain areas of the public sector. Its CG Code closely mimics the private sector. This means that in FTs AC members consist of NEDs with similar powers, influence and authority to exert as their private sector counterparts. Both AC Chairs comply with the requirement of having a financial background which is crucial as the predominant activity of the AC remains financial aspects. However, as the ACs have evolved to be able to cover the wider and different expectations, needs, aims and performance measurements of FTs there is deviation from simple isomorphism, with evidence of additional requirements for a broad spectrum of experience, multiplicity of skills, enquiring mind and general understanding within the AC too. In particular, the AC is encouraged to have at least one member with a health background to be able to deal with clinical governance elements which have become an integral

"This article is (c) Emerald Group Publishing and permission has been granted for this version to appear here (www.edgehill.ac.uk ). Emerald does not grant permission for this article to be further copied/distributed or hosted elsewhere without the express permission from Emerald Group Publishing Limited." 
part of the AC role. The latter is also reflected in terms of the training offered to NEDs, which focuses around NHS related elements to cover the diverse needs of FTs.

Furthermore, the role of the AC is also extended now to include increased emphasis on clinical aspects. These are also reflected in the targets and non-financial performance measurements set by Monitor and with which FTs are expected to comply.

In terms of the AC role and development in both FTs, the paper revealed that the development of the AC in terms of their roles and responsibilities has been very clear and led to improved accountability, especially evident in the AC meetings. This is obvious with the AC's increased authority in calling in any manager/director into the AC meetings and challenging them. Moreover, the AC has the right to scrutinize any decisions for additional assurance, clarification and explanation and triangulates its work with other committees.

It can be concluded that the AC development in FTs, as a new organisational form under the NHS, has been a relatively straightforward process. Initial homogeneity of structures and issues with private sector AC regulations derived from NPM influence, thus demonstrating mimetic isomorphism. Whilst an adverse effect of too much reliance on mimicking a structure designed for the private sector led to an overemphasis on financial governance, the AC remit is now more balanced with the inclusion of clinical issues. Overall Monitor acts as a coercive regulator requiring FTs to comply with its Code and financial and non-financial performance measures or else face sanctions. This has led to higher expectations from the NEDs in terms of focusing more on strategic goals of the FT.

In contrast, the IT frame of analysis provides evidence of only weak mimetic isomorphism for LA ACs. Unlike FTs there is no regulatory body and rather than a CG Code there are only CIPFA guidelines. Much of this difference is due to the political nature of LAs which is reflected in the more complex composition and appointment process of ACs. AC members are councillors with an arbitrary set of business skills, who are able to self-select to some extent, whether they want to serve on the AC or not. In addition, councillors are not elected on the basis of having relevant skills for the purpose of getting a diverse board, but instead are politically appointed with no requirement for having relevant or specific skills. More recently and to ensure independence, there is also an injection of independent appointed members who have a financial background are regarded as experts who provide more financial expertise. As

\footnotetext{
"This article is (c) Emerald Group Publishing and permission has been granted for this version to appear here (www.edgehill.ac.uk ). Emerald does not grant permission for this article to be further copied/distributed or hosted elsewhere without the express permission from Emerald Group Publishing Limited."
} 
ACs are relatively new in LAs the IA also run training sessions which focus around AC members getting a better understanding of their roles and duties and any further expectations.

Consequently, in LAs the adoption of ACs has been less uniform than in FTs and there still remain doubts as to whether ACs are seen as regulatory or scrutiny type committees. The study found that the AC's main responsibility is around monitoring and acting as whistle-blowers. Furthermore, the study provided evidence on how accountability has improved in LAs through the AC's increased scrutinizing and challenging roles. The AC role not only focuses on financial aspects but also includes non-financial performance measurements especially around VFM arrangements, anti-Fraud and anti-corruption items and compliance with codes and standards. The AC's role is to approve targets set by the different departments within the LA rather than setting their own policies.

Moreover, in LAs ACs still remain in a development phase but are gradually improving in terms of their scrutinizing and challenging responsibilities. More so, there has been a growing competence of AC members' understanding of their prescribed roles and duties. Yet the political and more complex set-up of the AC means it has developed differently to ACs in FTs.

To sum up, Institutional Theory gives an initial explanation of why ACs were set up in FTs and LAs, with mimetic isomorphism being particularly evident in the regulations for FT ACs. However, the analysis shows that as FTs and LAs operate in environments with diverse institutional settings, structures and organizational contexts the varying development of the AC in both is not unexpected. In particular, the regulatory environment shows the different isomorphic tendencies between the two sectors, with isomorphism bordering on the coercive for FTs, whilst for LAs mimetic isomorphism is much weaker. Nevertheless, both recognize that having an effective working AC is incremental and can benefit organisations in terms of improved accountability, increased probity and transparency in reporting, better VFM arrangements and high quality services being offered to the general public.

\section{Conclusion}

As most previous research on ACs has focused on structural characteristics of the ACs independence, financial expertise, meeting frequency or on whether ACs comply with related rules (Abbot et al., 2004; Larcker et al., 2007; Ghafran and O’Sollivan, 2013), this study sought to address the gap on how ACs actually perform and operate in practice. The use of an IT lens

"This article is (c) Emerald Group Publishing and permission has been granted for this version to appear here (www.edgehill.ac.uk ). Emerald does not grant permission for this article to be further copied/distributed or hosted elsewhere without the express permission from Emerald Group Publishing Limited." 
has enabled the research to go beyond checking for relationships and correlations between AC elements and other measures of performance to gain more nuanced insights from the organizations themselves; in this case through comparing ACs in two public sector contexts. As the previous literature implied that non-profit ACs are mostly independent (Vermeer et al., 2006) and that financial expertise is not considered an important qualification for serving on a non-profit AC (West and Berman, 2009) research on the AC needs to go beyond only examining these characteristics. So, this study investigated different AC elements such as the AC's composition, roles, and development, through the use of multiple research methods, to get deeper insights on the AC operation in two distinct English public sector settings.

The findings are in line with BoardSource (2010) which implied that public sector ACs have diverse structures and working mechanisms. However, unlike earlier studies by Miller (2002) and Hillman and Dalziel (2003) who find that ACs function weakly in the non-profit sector this research has found developments and progress within the AC roles and responsibilities. Although ACs, especially LAs, are still developing, they cannot be seen as "a dead hand but as a force for good and a force for change".

This study only partly agrees with Davies (2009), Van der Nest (2008) and Magrane and Mathus (2010) that there still remains a lack of understanding and proper application of some AC functions and responsibilities and that AC members still need to become more familiar and gain more expertise with operational processes relating to the public sector as there have been improvements since these earlier studies. As ACs are relatively new, particularly in LAs, AC members in FTs and LAs run through different internally arranged training programs held by the EA, IA and briefings from external visitors. These are especially designed for AC members for an increased perception of their responsibilities and for them to gain a more comprehensive understanding of the wide range of issues, strategic processes and institutional needs in FTs and LAs. This also led to improvements in the AC remit and operation in terms of their monitoring and challenging responsibilities especially evident by focusing on more strategic targets and goals.

Using an IT lens, this exploratory study finds that mimetic isomorphism is insufficient to offer a full explanation of AC development in a complex public sector environment, where different institutional pressures impinge on AC development in different functional sectors. The findings provided about ACs in the two distinct English public sector environments challenge simple

"This article is (c) Emerald Group Publishing and permission has been granted for this version to appear here (www.edgehill.ac.uk ). Emerald does not grant permission for this article to be further copied/distributed or hosted elsewhere without the express permission from Emerald Group Publishing Limited." 
explanations drawn from mimetic isomorphism because they offer evidence that the level of regulatory coercion leads to differences in approach in terms of the AC composition, roles and responsibilities in both sectors, and that ACs are developing distinctive public sector approaches to their work in holding their boards to account.

In conclusion, this study can be viewed as a base or starting point on which future studies can build. Critics of qualitative case study research may argue that as the findings are based on a specific context, setting and only four cases, the claimed contributions to knowledge may not pass the test of statistical generalisation; that is, they lack external validity and limit the scope and extent of the issues examined. Nevertheless, using multiple sources of data and confirmation of information relating to the documentary analysis at the interviews helped to improve corroboration and add reassurance to the findings.

As public sector reform continues, further longitudinal study of such ACs is needed, across the full spectrum of the public sector, so that this noticeable AC development in terms of the structures and practices can continue to be examined. In particular, the AC can be examined in further depth for FTs and LAs or in further public sector environments such as in schools, universities, central government and housing. These studies can also be applied and used at a national or an international level.

Furthermore, the study of U.K public sector ACs may open the door for comparisons between ACs in public versus private sector organizations or between different environments in the public sector itself. These studies can be of benefits to both the private and public sector through the identification of elements of strengths and weaknesses in both and the ability to implement elements of strength identified in one sector into another.

\section{Notes}

1. At the Stafford Hospital, run by the Mid-Staffordshire NHS Foundation Trust, there were high mortality rates, serious failings in the care and treatment of patients and unacceptable standards of hygiene and infection control. The governance regime had no effective role in challenging management as it focused on financial issues rather than patient care. The subsequent Francis Report (2013) had 290 recommendations for improvement.

2. Serious failings in the care and treatment of patients were discovered, as well as unacceptable standards of hygiene and infection control in an elderly care home in Bristol.

3. Hands-on top management refers to managers who are highly involved in the day-to-day activities and decisions of the organisation to promote problem-free, productive operations. They offer continual support and coaching to their employees to help ensure they are fully engaged in achieving success.

\footnotetext{
"This article is (c) Emerald Group Publishing and permission has been granted for this version to appear here (www.edgehill.ac.uk ). Emerald does not grant permission for this article to be further copied/distributed or hosted elsewhere without the express permission from Emerald Group Publishing Limited."
} 


\section{References}

Abbott, L.J. \& Parker, S. \& Peters, G.F. \& Raghunandan, K. (2003a), The association between audit committee characteristics and audit fees, Auditing: A Journal of Practice \& Theory, 22, 17-32.

Abbott, L.J. \& Parker, S. \& Peters, G.F. (2004), “Audit Committee characteristics and restatements”, Auditing: Journal of Practice \& Theory, 19(2), 47-66.

Archambeault, D.S. \& DeZoort, F.T. \& Hermanson, D.R. (2008), Audit committee incentive compensation and accounting restatements, Contemporary Accounting Research, 25, 965-992.

Aristovnik, A. (2009), "Performance budgeting: selected international experiences and some lessons for Slovenia," MPRA Paper 15499, University Library of Munich, Germany.

Beasley, M. \& Carcello, J. \& Hermansson, D. \& Neal, L. (2009), The audit committee oversight process, Contemporary Accounting Research, Vol.26, No.1, 65-122.

Bedard, J. \& Coulombe, D. \& Courteau, L. (2008), Audit committee, under-pricing of IPOs, and accuracy of management earnings forecasts, Corporate Governance: An International Review, 16, 519-535.

Bedard, J. \& Gendron, Y. (2010), Strengthening the Financial Reporting System: Can Audit Committees Deliver? International Journal of Auditing, 14 (2), 174-210.

BoardSource, (2010), BoardSource Non-profit Governance Index 2010, http//www.boardsource.org/dl.asp?document_id=884 (accessed July 13, 2011).

Broadbent, J. \& Guthrie, J. (2008), Public sector to public services: 20 years of contextual accounting research, Accounting, Auditing \& Accountability Journal, 21 (2), 129-169.

Cadbury Committee (1992), Report of the Committee on the financial aspects of corporate Governance, The Cadbury Report, December 1992.

Carcello, J.V. \& Neal, T. L. (2000), Audit committee composition and auditor reporting, The Accounting Review, 75(4), 453-467.

Chandrasegaram, R. \& Rahimansa, R. \& Rahman, K. \& Abdullah, S. \& Mat, N. (2013), Impact of Audit Committee Characteristics on Earnings Management in Malaysian Public Listed Companies, International Journal of Finance and Accounting, 2(2), 114-119.

Chien, W. W. \& Mayer, R. W. \& Sennetti, J. T. (2010), Audit committee effectiveness in the largest US public hospitals: an empirical study, Accounting \& Taxation, 2(1), 107-127.

Christopher, J. (2010), Corporate governance - A multi-theoretical approach to recognizing the wider influencing forces impacting on organizations, Critical perspectives on accounting, 21(8), 683-695.

Christopher, J. E. (2012), The adoption of internal audit as a governance control mechanism in Australian public universities - views from the CEOs, Journal of Higher Education Policy and Management 34 (5): 529-541.

"This article is (c) Emerald Group Publishing and permission has been granted for this version to appear here (www.edgehill.ac.uk ). Emerald does not grant permission for this article to be further copied/distributed or hosted elsewhere without the express permission from Emerald Group Publishing Limited." 
CIPFA (The Chartered Institute of Public Finance and Accountancy)(2013), Audit Committees-Practical Guidance for Local Authorities, (Chartered Institute of Public Finance and Accountancy, London).

CIPFA (2007), Delivering good Governance in Local Government, bodies, (Chartered Institute of Public Finance and Accountancy, London).

CIPFA (2005), Audit Committees-Practical Guidance for Local Authorities, (Chartered Institute of Public Finance and Accountancy, London).

Cohen, J. \& Krishnamoorthy, K. \& Wright, A. (2002), Form versus substance: Their implication for auditing practice and research of alternative perspectives on corporate governance, Corporate Governance and the audit process contemporary accounting research, 19 (4): 573-94.

Cohen, J. \& Krishnamoorthy, G. \& Wright, A. (2007), Corporate Governance and the audit process, Contemporary accounting research, 19 (4): 573-94.

Dart, R. (2004), The legitimacy of social enterprise, Non-profit management and leadership, 14(4), 411-424.

Davies, M. (2009), Effective working relationships between audit committees and internal audit- the cornerstone of corporate governance in local authorities, a Welsh perspective, Journal of Management \& Governance, 13(1-2), 41-73.

Dillard, J. F. \& Rigsby, J. T. \& Goodman, C. (2004), The making and remaking of organization context: duality and the institutionalization process, Accounting, Auditing \& Accountability Journal, 17(4), 506-542.

Di Maggio, P. \& Powell, W. (1983), The iron cage revisited: Institutional Isomorphism and Collective Rationality in organizational fields, American Sociological Review, Volume 48, Issue 2, 147-160.

Evan, W. M. \& Edward-Freeman, R. (1990), Corporate governance: A stakeholder interpretation, Journal of Behavioural Economics, 19(4), 337-359.

Francis

Report

(2013),

http://webarchive.nationalarchives.gov.uk/20150407084003/http://www.midstaffspublicinqui

ry.com/report, (Accessed 20 $0^{\text {th }}$ November, 2015)

Ghafran, C. \& O'Sullivan, N. (2013),"The Governance Role of Audit Committee: Reviewing a Decade of Evidence", International Journal of Management Review, 15, 381-407.

Ghobadian, A. \& Viney, H. \& Redwood, J.(2009), Explaining the unintended consequences of public sector reform, Management Decision, Vol.47 No.10, 1514-1535.

Glynn, J. J. (1985), Value for money auditing - an international review and comparison, Financial Accountability and Management, 1 (2), 113-128.

Hawley, A. (1968), Human Ecology, International Encyclopaedia of the Social sciences, New York: Macmillan, 328-37.

\footnotetext{
"This article is (c) Emerald Group Publishing and permission has been granted for this version to appear here (www.edgehill.ac.uk ). Emerald does not grant permission for this article to be further copied/distributed or hosted elsewhere without the express permission from Emerald Group Publishing Limited."
} 
Higgs Report (2003), Review of the role and effectiveness of non-executive directors. Available at: http://www.ecgi.org/codes/documents/higgsreport.pdf (date accessed 30 July 2012).

Hillman, A. \& Dalziel, T. (2003), Board of directors and firm performance: Integrating agency and resource dependency perspectives, Academy of Management review, Vol.28, No 3, 383-96.

Hood, C. (1991), A public management for all seasons, Public administration, 69(1), 3-19.

Hood, C. (1995), The "New Public Management" in the 1980s: variations on a theme, Accounting, organizations and society, 20(2), 93-109.

Humphrey, C. \& Miller, P. (2012), Rethinking impact and redefining responsibility: The parameters and coordinates of accounting and public management reforms, Accounting, Auditing \& Accountability journal, 25(2), 295-327.

Jacobs, K. (2012), Making sense of social practice: theoretical pluralism in public sector accounting research, Financial Accountability \& Management, 28(1), 1-25.

Larcker, D. \& Richardson, S. \& Tuna, I. (2007), "Corporate governance, Accounting Outcomes, and Organizational performance”, The Accounting Review, 82, 963-1008.

Liao, C. \& Wen-Hsin Hsu, A. (2013), "Common Membership and Effective Corporate Governance: Evidence from Audit and Compensation Committee", Corporate Governance: An International Review, 21(1), 79-92.

Magrane, J. \& Malthus, S. (2010), Audit committee effectiveness: a public sector case study, Managerial Auditing Journal, 25(5), 427-443.

McKernan, J. and McKernan, J. (2013), "Curriculum Action Research: A handbook of Methods and Resources for the Reflective Practitioner”, London: Routledge.

Meyer, J. W. \& Rowan, B. (1977), Institutionalized organizations: Formal structure as myth and ceremony, American journal of sociology, 340-363.

Miller, J. (2002), The board as a monitor of organizational activity: The applicability of agency theory to non-profit boards, Management and Leadership, Vol.12, No.4, 429-50.

Monitor, (2014), NHS Foundation Trusts Code of Governance, https://www.gov.uk/government/uploads/system/uploads/attachment_data/file/327068/Codeof GovernanceJuly2014.pdf, (accessed June 2013).

Monitor, (2013), A brief guide for NHS foundation trust governors by Monitor, Publication code: IRGG 01/14.

Myers, J. \& Sacks, R. (2003), Tools, Techniques and Tightropes: The Art of Walking and Talking Private Sector Management in Non-profit Organisations, is it Just a Question of Balance? Financial Accountability \& Management, 19(3), 287-306.

\footnotetext{
"This article is (c) Emerald Group Publishing and permission has been granted for this version to appear here (www.edgehill.ac.uk ). Emerald does not grant permission for this article to be further copied/distributed or hosted elsewhere without the express permission from Emerald Group Publishing Limited."
} 
National Audit Office. (2000), Getting value for money from procurement: How auditors can help? Office of Government Commerce, Available from http://www.nao.org.uk/wpcontent/uploads/2013/02/vfmprocurementguide.pdf (accessed 25 August 2014)

Nolan report (1995) "First Report of the Committee on Standards in Public Life" (PDF), Committee on Standards in Public Life, (last accessed 19 October 2013).

Parker, L. D. \& Guthrie, J. (1993), The Australian public sector in the 1990s: new accountability regimes in motion, Journal of International Accounting, Auditing and Taxation Volume 2, Issue 1, 59-81.

Pollitt, C. (2011), 'Moderation in all things: International comparisons of governance quality', Financial Accountability and Management, 27 (4), 437-457.

Pollitt, C. \& Bouckaert, G. (2011), Public management reform: A comparative analysis-new public management, governance, and the Neo-Weberian state, Oxford University Press.

Pridgen, A. \& Wang, K.J. (2012), Audit Committees and Internal Control Quality: Evidence from Non-profit Hospitals Subject to the Single Audit Act, International Journal of Auditing, Vol 16 (2), 165-183.

Purcell, A. \& Francis, R. \& Clark, C. (2014), Audit Committee Effectiveness in Victorian Local Government, Australian Accounting Review, No. 71, Vol.24 (4), 339-369.

Rainsbury, E. A. \& Malthus, S. \& Capper, P. A. (2012), The Existence and Composition of Audit Committees in the New Zealand Public Sector, Australian Accounting Review, 22(1), 103-113.

Rea, L. M. \& Parker, R. A. (2012), Designing and conducting survey research: A comprehensive guide, John Wiley \& Sons.

Rich, K. \& Zhang, J. (2014), Does Audit Committee Monitoring Matter in the Government Sector? Evidence from Municipal Internal Control Quality, Evidence from Municipal Internal Control Quality, Electronic copy available at: http://ssrn.com/abstract=2388292.

Rogers, M. (2006), Contingent Corporate Governance: A challenge to universal theories of board structure, PhD thesis, University of New South Wales, Kensington.

Smith Report, (2003), Audit committee combined code guidance, Financial Reporting Council Ltd London.

Smyth, S. (2012), Contesting public accountability: A dialogical exploration of accountability and social housing, Critical Perspectives on Accounting, 23(3), 230-243.

Spira, L. (2002), The audit committee: Performing Corporate Governance, London: Kluwer academic Publishers.

Spira, L. (2003), Audit Committees: begging the question? Corporate Governance: An International Review, 11, 180-188.

Spira, L. F. \& Bender, R. (2004), Compare and contrast: perspectives on board committees, Corporate Governance: An International Review, 12(4), 489-499.

The Independent Commission on Good Governance in Public services (2004), The Good "This article is (c) Emerald Group Publishing and permission has been granted for this version to appear here (www.edgehill.ac.uk ). Emerald does not grant permission for this article to be further copied/distributed or hosted elsewhere without the express permission from Emerald Group Publishing Limited." 
Governance Standard for Public services (Langland Report), http://www.cipfa.org/-

/media/Files/Publications/Reports/governance_standard.pdf (date accessed June 2014).

The UK Corporate Governance code (2014), https://www.frc.org.uk/OurWork/Publications/Corporate-Governance/UK-Corporate-Governance-Code-2014.pdf, (date accessed $10^{\text {th }}$ October, 2015)

Turley, S. and Zaman, M. (2007), Audit Committee effectiveness: informal processes and Behavioural effect, Accounting, Auditing \& Accountability Journal, 20, (5), 765-788.

Turley, S. and Zaman, M. (2004), Corporate governance effects of audit committee, Journal of Management \& Governance, 8, 305-332.

Van der Nest, A. (2008), The perceived effectiveness of audit committees in the South African public service, Management, 16(2), 175-188.

Vermeer, T. \& Raghunadan, K. \& Forgione, D.A. (2006), The composition of non-profit audit committees, Accounting Horizon, Vol .20, No.1, 75-90.

West, J.P. \& Berman, E.M. (2003), Audit Committees and accountability in local government: A national survey, International Journal of Public Administration, Vol. 26, No.4, 329-362.

Xie, B. \& Davidson, W.N. \& DaDalt, P.J. (2003), Earnings management and corporate governance: the role of the board and the audit committee, Journal of Corporate Finance, 9, (2), 292-316.

Yin, R. K. (2003), Applied social research methods series, Case study research: Design and methods, 5.

Zaman, M. \& Hudaib, M. \& Haniffa, R. (2011), Corporate governance quality, audit fees and non-audit services fees, Journal of Business Finance and Accounting, 38, 165- 197.

\footnotetext{
"This article is (c) Emerald Group Publishing and permission has been granted for this version to appear here (www.edgehill.ac.uk ). Emerald does not grant permission for this article to be further copied/distributed or hosted elsewhere without the express permission from Emerald Group Publishing Limited."
} 


\section{List of Tables}

Table 1: Interviews undertaken

\begin{tabular}{|l|c|c|c|c|c|}
\hline & $\begin{array}{c}\text { Foundation } \\
\text { Trust } \\
\text { (North) }\end{array}$ & $\begin{array}{c}\text { Foundation } \\
\text { Trust } \\
\text { (South) }\end{array}$ & $\begin{array}{c}\text { Local } \\
\text { Authority } \\
\text { (East) }\end{array}$ & $\begin{array}{c}\text { Local } \\
\text { Authority } \\
\text { (West) }\end{array}$ & $\begin{array}{c}\text { Further } \\
\text { organizations }\end{array}$ \\
\hline AC Chair & $\checkmark$ & $\checkmark$ & $\checkmark$ & $\checkmark$ & $\checkmark / \checkmark$ \\
\hline Finance Director & $\checkmark$ & $\checkmark$ & n/a & n/a & $\checkmark$ \\
\hline Internal Auditor & $\checkmark^{*}$ & $\checkmark^{*}$ & $\checkmark$ & $\checkmark$ & \\
\hline External Auditor & $\checkmark^{*}$ & $\checkmark^{*}$ & $\checkmark$ & $\checkmark$ & \\
\hline $\begin{array}{l}\text { Audit Committee } \\
\text { meeting }\end{array}$ & $\checkmark$ & $\checkmark$ & $\checkmark$ & $\checkmark$ & \\
\hline
\end{tabular}

* These were unstructured discussions

"This article is (c) Emerald Group Publishing and permission has been granted for this version to appear here (www.edgehill.ac.uk ). Emerald does not grant permission for this article to be further copied/distributed or hosted elsewhere without the express permission from Emerald Group Publishing Limited." 
Table 2: Requirements in relation to AC structures for Foundation Trusts and Local Authorities

\begin{tabular}{|c|c|c|c|c|}
\hline & $\begin{array}{l}\text { Monitors' Code of } \\
\text { Governance (2014) }\end{array}$ & $\begin{array}{l}\text { CIPFA Guidelines on AC } \\
\text { (2013) }\end{array}$ & $\begin{array}{l}\text { Foundation Trusts } \\
\text { (North and South) }\end{array}$ & $\begin{array}{l}\text { Local Authorities } \\
\text { (East and West) }\end{array}$ \\
\hline $\begin{array}{l}\text { Composition } \\
\text { and } \\
\text { Membership }\end{array}$ & $\begin{array}{l}\text { The AC membership } \\
\text { should consist of at least } 3 \\
\text { independent NEDs }\end{array}$ & $\begin{array}{l}\text { The size of the } \mathrm{AC} \text { is encouraged } \\
\text { to be between } \mathbf{3} \text { and } 5 \text { members. }\end{array}$ & $\begin{array}{l}\text { Both FTs vary from having } 3 \text { to } 6 \\
\text { AC members. }\end{array}$ & $\begin{array}{l}\text { Both LAs vary from having } 10 \text { to } 12 \text { AC members } \\
\text { including independent members. }\end{array}$ \\
\hline $\begin{array}{l}\text { Appointment } \\
\text { of AC } \\
\text { members }\end{array}$ & Nothing mentioned & $\begin{array}{l}\text { The AC Membership should } \\
\text { abide by the rules concerning the } \\
\text { political structure of the LA } \\
\text { which depends on its make-up } \\
\text { and history. }\end{array}$ & $\begin{array}{l}\text { When considering the } \\
\text { appointment of NEDs, the } \\
\text { governors take into account the } \\
\text { views of the board of directors } \\
\text { on the qualifications, skills and } \\
\text { experience required for each } \\
\text { position. }\end{array}$ & $\begin{array}{l}\text { Appointment process all about choice and all } \\
\text { councillors other than on executive committees can be } \\
\text { appointed. } \\
\text { The number of opposition members is decided based on } \\
\text { the overall proportion of the LAs political structure. }\end{array}$ \\
\hline $\begin{array}{l}\text { Financial } \\
\text { experience }\end{array}$ & $\begin{array}{l}\text { One member, preferably } \\
\text { the Chair, should have } \\
\text { recent and relevant } \\
\text { financial experience. }\end{array}$ & $\begin{array}{l}\text { Guidelines encourage the } \\
\text { injection of an external view as } \\
\text { independent members. }\end{array}$ & $\begin{array}{l}\text { Both FTs benefit from having one } \\
\text { CIPFA qualified AC chair with } \\
\text { vast experience in local } \\
\text { government and the other with } \\
\text { financial background as a retired } \\
\text { KPMG partner. }\end{array}$ & $\begin{array}{l}\text { The independent members add a different } \\
\text { dimension by viewing AC issues from the perspectives } \\
\text { of their local community and as local taxpayers. } \\
\text { One independent member is a retired business } \\
\text { partner whereas the other member is a local rabbi and } \\
\text { a qualified accountant. }\end{array}$ \\
\hline $\begin{array}{l}\text { Make-up skills } \\
\text { and experience } \\
\text { of members }\end{array}$ & $\begin{array}{l}\text { Having a broad spectrum } \\
\text { of experience and skills } \\
\text { within the members is } \\
\text { crucial to discharge its } \\
\text { responsibilities effectively. }\end{array}$ & $\begin{array}{l}\text { AC Chair should not be a } \\
\text { member of the Council } \\
\text { Executive for objectivity. } \\
\text { An accounting background is } \\
\text { less important than having a } \\
\text { broad understanding of the } \\
\text { financials, risk and controls, } \\
\text { core activities and general CG } \\
\text { issues. }\end{array}$ & $\begin{array}{l}\text { Broad spectrum of expertise and } \\
\text { experience within members } \\
\text { (commercial director of a large } \\
\text { energy company, a former director } \\
\text { of social services, a former CEO of } \\
\text { a city council, a lawyer and a } \\
\text { director of a big Pharma company } \\
\text { and a former senior audit partner). }\end{array}$ & $\begin{array}{l}\text { Importance of having a wide range of skills and } \\
\text { experience on the AC because a lot more functions to } \\
\text { cover in public organizations. } \\
\text { Two councillors have previously been Lord Mayors } \\
\text { interested in heritage assets, and Head of social } \\
\text { services with a good understanding of child protection. }\end{array}$ \\
\hline
\end{tabular}

CIPFA: The Chartered Institute of Public Finance and Accountancy

NEDs: Non-executive Directors
AC: Audit Committees

CG: Corporate Governance 